\title{
PENGERTIAN ANTROPOLOGI HUKUM
}

NAMA:ALSE AFRIADI

EMAIL:2812afriadi@gmail.com

NO BP:2010003600052

\section{UNIVERSITAS EKASAKTI}

\section{A.PENDAHULUAN}

\subsection{Latar Belakang}

Antropologi secara etimologis berasal dari bahasa Yunani. Kata Anthropos berarti mansia dan logos berarti ilmu pengetahuan. Jadi, antropologi adalah ilmu yang mempelajari manusia. Oleh karena itu antropologi didasarkan pada kemajuan yang telah dicapai ilmu pengetahuna sebelumnya.

Pitirim Sorokim mengatakan bahwa Sosiologi adalah suatu ilmu yang mempelajari hubungan dan pengaruh timbal balik antara aneka macam gejala-gejala sosial (gejala ekonomi dengan agama, keluarga dengan moral, hukum dengan ekonomi) dengan gejala lainnya (nonsosial). Berbeda dengan pendapat Rouceke dan Warren yang mengatakan bahwa Sosiologi adalah ilmu yang mempelajari hubungan manusia dengan kelompok-kelompok.

Nah berasarkan uraian di atas, maka Sosiologi adalah jelas merupakan ilmu sosial yang objeknya adalah masyarakat sebagai ilmu. Ia berdiri sendiri karena telah memiliki unsur ilmu pengetahuan. 
Dalam ilmu antropologi hukum dipelajari juga mengenai Peran, Status atau kedudukan, Nilai, Norma dan juga Budaya atau kebudayaan. Kesemuanya ini merupakan hal-hal yang sangat erat kaitannya dengan ilmu antropologi hukum

\subsection{Rumusan Masalah}

1. Apakah pengertian antropologi hukum?

2. Apakah pengertian Status/kedudukan dalam ilmu antropologi hukum?

3. Apakah pengertian Nilai dalam ilmu antropologi hukum?

4. Apakah pengertian Norma dalam ilmu antropologi hukum?

5. Apakah pengertian Budaya/Kebudayaan dalam ilmu antropologi hukum?

\subsection{Maksud dan Tujuan}

1. Memberikan gambaran teori mengenai Peran, Status, Nilai, Norma, dan juga Budaya/kebudayaan dalam kaitannya dengan masyarakat sebagai sasaran ilmu Sosiologi.

2. Sebagai arahan agar saya sebagai mahasiswa dapat mengkorelasikan hubungan antara teori Peran, Status, Nilai, Norma dan Budaya/kebudayaan dengan kehidupan masyarakat di kehidupan yang nyata. 


\section{B.PEMBAHASAN}

\subsection{Pengertian Antropologi}

Antropologi berasal dari kata Yunani yaitu anthropos yang berarti "manusia" atau "orang", dan logos yang berarti ilmu. Antropologi mempelajari manusia sebagai makhluk biologis sekaligus makhluk sosial. Antropologi memiliki dua sisi holistik dimana meneliti manusia pada tiap waktu dan tiap dimensi kemanusiannya. Arus utama inilah yang secara tradisional memisahkan antropologi dari disiplin ilmu kemanusiaan lainnya yang menekankan pada perbandingan/ perbedaan budaya antar manusia. Walaupun begitu sisi ini banyak diperdebatkan dan menjadi kontroversi sehingga metode antropologi sekarang seringkali dilakukan pada pemusatan penelitan pada pendudukyang merupakan masyarakat tunggal.

\section{Definisi Antropologi menurut para ahli}

- William A. Havilan: Antropologi adalah studi tentang umat manusia, berusaha menyusun generalisasi yang bermanfaat tentang manusia dan perilakunya serta untuk memperoleh pengertian yang lengkap tentang keanekaragaman manusia.

- David Hunter:Antropologi adalah ilmu yang lahir dari keingintahuan yang tidak terbatas tentang umat manusia.

- Koentjaraningrat: Antropologi adalah ilmu yang mempelajari umat manusia pada umumnya dengan mempelajari aneka warna, bentuk

fisik masyarakat serta kebudayaan yang dihasilkan.

Dari definisi tersebut, dapat disusun pengertian sederhana antropologi, yaitu sebuah ilmu yang mempelajari manusia dari segi keanekaragaman fisik serta kebudayaan (cara-cara berprilaku, tradisi-tradisi, nilai-nilai) yang dihasilkan sehingga setiap manusia yang satu dengan yang lainnya berbeda-beda. 


\subsection{PENGERTIANN STATUS/KEDUDUKAN DALAM ANTROPOLOGI HUKUM}

(status) diartikan sebagai tempat atau posisi seseorang dalam suatu kelompok sosial.

Sedangkan kedudukan sosial (social status) artinya tempat seseorang secara umum dalam masyarakatnya sehubungan dengan orang lain, dalam arti lingkungan pergaulannya, prestisenya, dan hak-hak serta kewajiban-kewajibannya. Namun untuk mempermudah dalam pengertiannya maka dalam kedua istilah di atas akan dipergunakan dalam arti yang sama dan digambarkan dengan istilah "kedudukan" (status) saja. Masyarakat pada umumnya mengembangkan dua macam kedudukan(status), yaitu sebagai berikut :

Ascribed Status yaitu kedudukan seseorang dalam masyarakat tanpa memerhatikan perbedaan-perbedaaan rohaniah dan kemampuan. Kedudukan ini diperoleh karena kelahiran Achieved Status yaitu kedudukan yang dicapai oleh seseorang dengan usaha-usaha yang disengaja. Kedudukan ini bersifat terbuka bagi siapa saja, tergantung dari kemampuan masing-masing dalam mengejar serta mencapai tujuan-tujuannya.

Kadang-kadang dibedakan lagi satu macam kedudukan, yaitu Assigned Status yang merupakan kedudukan yang diberikan. Status ini sering berhubungan erat dengan Achieved Status, dalam arti bahwa suatu kelompok atau golonganmemberikan kedudukan yang lebih tinggi kepada seseorang yang berjasa yang telah memperjuangkan sesuatu untuk memenuhi kebutuhan dan kepentingan masyarakat.

\subsection{PENGERTIAN NILAI DALAM ILMU ANTROPOLOGI HUKUM}

Nilai sosial adalah nilai yang dianut oleh suatu masyarakat, mengenai apa yang dianggap baik dan apa yang dianggap buruk oleh masyarakat. Sebagai contoh, orang menanggap menolong memiliki nilai baik, sedangkan mencuri bernilai buruk. Woods mendefinisikan nilai sosial 
sebagai petunjuk umum yang telah berlangsung lama, yang mengarahkan tingkah laku dan kepuasan dalam kehidupan sehari-hari.

Untuk menentukan sesuatu itu dikatakan baik atau buruk, pantas atau tidak pantas harus melalui proses menimbang. Hal ini tentu sangat dipengaruhi oleh kebudayaan yang dianut masyarakat. tak heran apabila antara masyarakat yang satu dan masyarakat yang lain terdapat perbedaan tata nilai. Contoh, masyarakat yang tinggal di perkotaan lebih menyukai persaingan karena dalam persaingan akan muncul pembaharuan-pembaharuan. Sementara apda masyarakat tradisional lebih cenderung menghindari persaingan karena dalam persaingan akan mengganggu keharmonisan dan tradisi yang turun-temurun.

Drs. Suparto mengemukakan bahwa nilai-nilai sosial memiliki fungsi umum dalam masyarakat. Di antaranya nilai-nilai dapat menyumbangkan seperangkat alat untuk mengarahkan masyarakat dalam berpikir dan bertingkah laku. Selain itu, nilai sosial juga berfungsi sebagai penentu terakhir bagi manusia dalam memenuhi peranan-peranan sosial. Nilai sosial dapat memotivasi seseorang untuk mewujudkan harapan sesuai dengan peranannya. Contohnya ketika menghadapi konflik, biasanya keputusan akan diambil berdasarkan pertimbangan nilai sosial yang lebih tinggi. Nilai sosial juga berfungsi sebagai alat solidaritas di kalangan anggota kelompok masyarakat. Dengan nilai tertentu anggota kelompok akan merasa sebagai satu kesatuan. Nilai sosial juga berfungsi sebagai alat pengawas (kontrol) perilaku manusia dengan daya tekan dan daya mengikat tertentu agar orang berprilaku sesuai dengan nilai yang dianutnya 


\subsection{PENGERTIAN NORMA DALAM ILMU ANTROPOLOGI HUKUM}

Norma dalam antropologi hukum adalah seluruh kaidah dan peraturan yang diterapkan melalui lingkungan sosialnya. Sanksi yang diterapkan oleh norma ini membedakan norma dengan produk sosial lainnya seperti budaya dan adat. Ada/ tidaknya norma diperkirakan mempunyai dampak dan pengaruh atas bagaimana seseorang berperilaku.

Dalam kehidupannya, manusia sebagai mahluk sosial memiliki ketergantungan dengan manusia lainnya. Mereka hidup dalam kelompok-kelompok, baik kelompok komunal maupun kelompok materiil.

Kebutuhan yang berbeda-beda, secara individu/kelompok menyebabkan benturan kepentingan. Untuk menghindari hal ini maka kelompok masyarakat membuat norma sebagai pedoman perilaku dalam menjaga keseimbangan kepentingan dalam bermasyarakat.

\subsection{PENGERTIAN BUDAYA/KEBUDAYAAN DALAM ILMU ANTROPOLOGI HUKUM}

Budaya atau kebudayaan berasal dari bahasa Sansekerta yaitu buddhayah, yang merupakan bentuk jamak dari buddhi (budi atau akal) diartikan sebagai hal-hal yang berkaitan dengan budi dan akal manusia. Dalam bahasa Inggris, kebudayaan disebut culture, yang berasal dari kata Latin Colere, yaitu mengolah atau mengerjakan. Bisa diartikan juga sebagai mengolah tanah atau bertani. Kata culture juga kadang diterjemahkan sebagai "kultur" dalam bahasa Indonesia.

Kebudayaan sangat erat hubungannya dengan masyarakat. Melville J. Herskovits dan Bronislaw Malinowski mengemukakan bahwa segala sesuatu yang terdapat dalam masyarakat ditentukan oleh kebudayaan yang dimiliki oleh masyarakat itu sendiri. Istilah untuk pendapat itu adalah Cultural-Determinism. Herskovits memandang kebudayaan 
sebagai sesuatu yang turun temurun dari satu generasi ke generasi yang lain, yang kemudian disebut sebagai superorganic. Menurut Andreas Eppink, kebudayaan mengandung keseluruhan pengertian, nilai, norma, ilmu pengetahuan serta keseluruhan struktur-struktur sosial, religius, dan lain-lain, tambahan lagi segala pernyataan intelektual dan artistik yang menjadi ciri khas suatu masyarakat.

Menurut Edward B. Tylor, kebudayaan merupakan keseluruhan yang kompleks, yang di dalamnya terkandung pengetahuan, kepercayaan, kesenian, moral, hukum, adat istiadat, dan kemampuan-kemampuan lain yang didapat seseorang sebagai anggota masyarakat.

Sedangkan menurut Selo Soemardjan dan Soelaiman Soemardi, kebudayaan adalah sarana hasil karya, rasa, dan cipta masyarakat.

Dari berbagai definisi tersebut, dapat diperoleh pengertian mengenai kebudayaan yang mana akan mempengaruhi tingkat pengetahuan dan meliputi sistem ide atau gagasan yang terdapat dalam pikiran manusia, sehingga dalam kehidupan sehari-hari, kebudayaan itu bersifat abstrak. Sedangkan perwujudan kebudayaan adalah benda-benda yang diciptakan oleh manusia sebagai makhluk yang berbudaya, berupa perilaku dan benda-benda yang bersifat nyata, misalnya pola-pola perilaku, bahasa, peralatan hidup, organisasi sosial, religi, seni, dan lain-lain, yang kesemuanya ditujukan untuk membantu manusia dalam melangsungkan kehidupan bermasyarakat

\section{C.PENUTUP}

\subsection{Kesimpulan}

Antropologi adalah ilmu yang mempelajari manusia. Oleh karena itu antropologi didasarkan pada kemajuan yang telah dicapai ilmu pengetahuan sebelumnya. Pengertian Antropologi 
dapat dilihat dari 2 sisi yaitu Antropologi sebagai ilmu pengetahuan artinya bahwa Antropologi merupakan kumpulan pengetahuan-pengetahuan tentang kajian masyarakat dan kebudayaan yang disusun secara sistematis atas dasar pemikiran yang logis. Dan pengertian Antropologi yang kedua adalah cara-cara berpikir untuk mengungkapkan realitassosial dan budaya yang ada dalam masyarakat dengan prosedur dan teori yang dapat dipertanggungjawabkan kebenarannya secara ilmiah.

Setelah di kaji kita dapat mengemukakan hasilnya bahwa manfaat di dalam antropologi hukum sangat luas.Antropologi hukum telah memberikan kontribusi yang sangat besar bangi perkembangan ilmu hukum.Dan kesimpulan yang dapat diambil adalah dimana pun kita ,kita tidak akan pernah jauh dari hukum selama kita berada di Negara hukum.

Peranan adalah aspek dinamis dari kedudukan, yaitu seorang yang melaksanakan hak-hak dan kewajibannya.Status adalah tempat atau posisi seseorang dalam suatu kelompok sosial. Sedangkan kedudukan sosial (social status) artinya tempat seseorang secara umum dalam masyarakatnya sehubungan dengan orang lain, dalam arti lingkungan pergaulannya, prestisenya, dan hak-hak serta kewajiban-kewajibannya.

Namun untuk mempermudah dalam pengertiannya maka dalam kedua istilah di atas akan dipergunakan dalam arti yang sama dan digambarkan dengan istilah "kedudukan" (status) saja. Nilai (Nilai Sosial) adalah nilai yang dianut oleh suatu masyarakat, mengenai apa yang dianggap baik dan apa yang dianggap buruk oleh masyarakat. Norma adalah seluruh kaidah dan peraturan yang diterapkan melalui lingkungan sosialnya. Budaya adalah hal-hal yang berkaitan dengan budi dan akal manusia. Kebudayaan merupakan keseluruhan pengertian, nilai, norma, ilmu pengetahuan serta keseluruhan struktur-struktur sosial, religius, dan lainlain, tambahan lagi segala pernyataan intelektual dan artistik yang menjadi ciri khas suatu masyarakat. 
